\title{
Human Resource Management Practices And Organizational Innovation: An Empirical Study In Malaysia
}

Tan Cheng Ling, Universiti Sains Malaysia, Malaysia

Aizzat Mohd. Nasurdin, Universiti Sains Malaysia, Malaysia

\begin{abstract}
With rapid globalization, firms particularly those in the manufacturing sector have to continuously innovate for competitive advantage. One way to do so is via effective human resource management practices (thereafter termed as HRM). The purpose of this study is to examine the relationship between human resource management (HRM) practices and organizational innovation. We employed a cross-sectional design with a sample comprised of 674 large manufacturing companies from six states in Malaysia which were identified as having a high percentage of innovating companies (Ministry of Science, Technology and Innovation, Malaysia (MOSTI), 2006). Our independent variables comprised of five HRM practices (performance appraisal, career management, training, reward system, and recruitment). Three types of organizational innovation (product innovation, process innovation, and administrative innovation) served as our dependent variables. Our findings provided partial support for our main hypothesis. Training alone was found to have a positive and significant effect bon the three forms of organizational innovation. In addition, performance appraisal positively and significantly affects administrative innovation. Despite the fact that our research framework was partially supported, our study highlights the profound role played by training in stimulating organizational innovation in the context of the manufacturing industry of Malaysia. Implications of our findings and limitations of the research were discussed.
\end{abstract}

Keywords: HRM practices, organizational innovation, manufacturing industry, Malaysia.

\section{INTRODUCTION}

乌

ncreasing competitive pressure owing to globalization of manufacturing activities and ever-changing business environment have encouraged manufacturing firms to continuously immerse themselves in changing their processes, systems, techniques, and services to something newer and better, usually referred to as organizational innovation, to differentiate themselves from competitors. To achieve such standing, these organizations need to constantly focus on the capabilities of its workforce. It has been acknowledged that an organization's approach to human resource management is instrumental in eliciting positive work behaviors among employees, which in turn, enhances organizational innovation. Likewise, Damanpour and Gopalakrishnan (1998) highlight the role of HRM practices in predicting a firm's innovative behavior. According to Shipton, Fay, West, Patterson, and Birdi (2005), effective management of a firm's human resources would be able to promote innovation by enabling employees to create, transfer, and institutionalize knowledge. Harter, Schmidt, and Hayes (2002) suggested that HRM practices can generate increased knowledge, motivation, synergy, and commitment of a firm's workers, resulting in a source of sustained competitive advantage for the firm. However, very little research has addressed innovation from the perspective of HRM (Wolfe, 1995; Agarwala, 2003).

Organizational innovation has been widely examined within developed nations particularly in the United States of America and European countries (Damanpour, 1991; Damanpour, Szabat, \& Evan, 1989; Kimberly \& Evanisko, 1981; Lundvall \& Nielsen, 2007; Miller \& Friesen, 1982). For developing nations like Malaysia, studies on 
innovation are still in its infancy (Ismail, 2005; Mohamed, 1995; Wan Jusoh, 2000; Zain \& Rickards, 1996). In its efforts to become a knowledge-based economy, Malaysia has also placed great emphasis on the need for innovation in all sectors of its economy (Ministry of Science, Technology and Innovation, Malaysia (MOSTI), 2006). However, despite calls for greater innovative actions, the level of innovation in Malaysia is still low. In fact, Malaysia still lags even behind its nearest neighbor, Singapore. This can be gathered from the low GERD/GDP ratio for Malaysia for three consecutive years $(2002,2004$, and 2006) of 0.69, 0.63 and 0.64 respectively (MOSTI, 2006). On the other hand, Singapore's GERD/GDP ratio was almost three times greater than Malaysia. For instance, in 2002, 2004 and 2006, Singapore's GERD/GDP was recorded as 2.19, 2.25 and 2.39 respectively (European Commission, 2006).

Given the importance of innovation to a firm's competitive position, a number of studies have tried to identify the possible antecedents of innovation. The extant literature has grouped these factors into: individual, organizational, and environmental factors (Damanpour, 1991; Damanpour et al., 1989). Of all potential predictors of innovation, organizational variables have been argued as playing a pivotal role (Damanpour, 1991). Of the organizational variables, the literature has highlighted the role of HRM practices as a crucial input for organizational innovation (Jimenez-Jimenez \& Sanz-Valle, 2005; Shipton et al., 2005). HRM practices is claimed to establish the tone and conditions of the employee-employer relationship (Rousseau \& Greller, 1994). In turn, the tone and conditions of the employee-employer relationship can encourage or discourage employees to become more innovative. Most studies on HRM practices suggests that high-commitment practices (or innovative practices) by their very nature, enhance employee commitment (Agarwala, 2003). When employees believed that their organization's HRM practices as investments made by their employer, they are likely to reciprocate through positive work attitudes and behaviors, all of which are likely to stimulate innovation. Only with innovative employees, new ideas can be translated into reality (Schaffer \& Paul-Chowdhury, 2002). Against this backdrop, the goal of this study was to examine the effect of HRM practices (performance appraisal, career management, training, reward system, recruitment) on organizational innovation within the Malaysian manufacturing industry.

\section{MATERIALS AND METHODS}

\section{Organization Innovation (OI)}

Organizational innovation has been broadly defined as the adoption of idea or behavior new to the adopting organization (Damanpour \& Evan, 1984). Since innovation is conceived as a means of changing an organization, either as a response to changes in the external environment or as a preemptive action to influence the environment. Damanpour (1996) viewed innovation as encompassing a range of types, including new products or services, new process technologies, new organizational structures or administrative systems, or new plans or programs pertaining to organizational members. A review of the literature indicates that organizational innovation can be divided into two distinctive types: (1) technical or technological innovation; and (2) administrative innovation (e.g., Chuang, 2005; Damanpour \& Evan, 1984; Damanpour et al., 1989). However, Chuang (2005) has further categorized technical or technological innovation into secondary dimensions: product innovation and process innovation; while administrative innovation remains distinct from the other two. Since organizations adopt innovations continuously over time, it would be more accurate to depict innovations as comprising of multiple facets. Thus, in this study, organizational innovation is viewed as multidimensional, comprising of product innovation, process innovation, and administrative innovation. Product innovation also known as product development, is a systematic work process, drawing upon existing knowledge gained from research and practical experiences directed towards the production of new materials, products and devices, including prototypes (Hage \& Hollingsworth, 2005). Process innovation is defined as developing a new or substantially improved production process through new equipment or reengineering of operational process (Wong \& He, 2003). Generally, administrative innovation refers to performance derived from the changes in organizational structure and administrative process, reward and information system, and it encompasses basic work activities within the organization that is directly related to management (Chew, 2000; Damanpour \& Evan, 1984; Mavondo, Chimhanzi \& Stewart, 2005).

\section{Human Resource Management (HRM) Practices}

Globalization and competitive business environment have encouraged manufacturing-based industries to be proactive in their HRM practices in order to introduce new products and new technologies (Shipton et al., 2005). 
HRM practices can be almost everything coupled with management of employment relations within organization (Jackson \& Schuler, 1995). According to Jackson and Schuler (1995), HRM practices comprise of a system that attracts, develops, motivates, and retains employees to ensure the effective implementation and the survival of the organization and its members. Essentially, there are four main approaches to develop HRM: "universal" or "best practice" approach (Huselid, 1995); strategic HRM practices approach (Delery \& Doty, 1996); contingency approach (Dyer, 1985; Schuler, 1989); and configuration approach (Wright \& McMahan, 1992). However, previous studies revealed that HRM practices, which were related to organizational innovation, mainly focused on "universal" or "best practice" approach. These "universal" or 'best' HRM practices proposed by different scholars vary (Ferris, Hochwarter, Buckley, Harrell-Cook \& Frink, 1999). For instance, Delaney, Lewin and Ichniowski (1989) utilized ten 'best' HRM practices, which are selection, performance appraisal, incentive compensation, job design, grievance procedures, information sharing, attitude assessment, labor-management participation (Delaney et al., 1989 as cited in Ferris et al., 1999). On the other hand, Huselid (1995) added three more 'best' HRM practices on top of Delaney et al.'s (1989) list, which includes recruiting intensity, average training hours per year, and the criteria for promotion. A review of the literature demonstrates that most of these scholars in their studies of innovation, such as Gupta and Singhal (1993), Jiménez-Jiménez and Sanz-Valle (2005), Kydd and Oppenheim (1990), Laursen and Foss (2003), and Shipton et al. (2005) commonly agreed on five HRM practices, encompassing performance appraisal, career management, reward system, training, and recruitment. These studies focused on the extent or level of implementation of these practices.

\section{Human Resource Management (HRM) Practices and Organization Innovation (OI)}

The Ability, Motivation and Opportunity (AMO) theory contends that when employees are motivated, they are likely to perform better, leading to higher firm performance (Paauwe \& Boselie, 2005). Hiltrop (1996) provided evidence on the role of HRM practices as a powerful force in motivating employees to exhibit favorable attitudes and behaviors, all of which are required to support and implement the competitive strategy of an organization. According to Gupta and Singhal (1993), innovative companies will always seek to manage their human resources effectively to create and market new products and services. When firms develop innovation activities, such as introduce new product, new process and/or new administrative practices, they need innovative and creative employees, who are flexible, risk taking, and tolerant of uncertainty and ambiguity (Chen \& Huang, 2007). These employees are highly recognized in manufacturing industries because they will enable firms to compete on the basis of market responsiveness, as well as product and process quality. As such, it is important for a firm to adopt supportive HRM practices that can motivate and stimulate employees to be innovative. According to Jiménez-Jiménez and Sanz-Valle (2005), a stronger effect on organizational innovation can be expected through the adoption of a set or bundle of complementary HRM practices. Their study revealed that the adoption of some HRM practices (such as participation and use of promotion plans) significantly explain the firm's innovation orientation. Agarwala (2003) argued that organizations need to continually modify their HRM practices in line with the changing business environment and growing expectations and aspirations of the workforce. By doing so, employee commitment will be fostered, which in turn lead to improved performance for the organization and also improved well-being and development for the employees. Although no consensus has been made as to what constitutes 'best' practices, a review of the literature on HRM practices has identified five common practices that are bound to make a difference to the business results: performance appraisal (Gupta \& Singhal, 1993; Jiménez-Jiménez \& Sanz-Valle, 2005; Kydd \& Oppeneheim, 1990; Shipton et al., 2005), career management (Gupta \& Singhal, 1993; Jiménez-Jiménez \& Sanz-Valle, 2005; Kydd \& Oppeneheim, 1990; Laursen \& Foss, 2003), training (Jiménez-Jiménez \& Sanz-Valle, 2005; Laursen \& Foss, 2003; Shipton et al., 2005), reward system (Gupta \& Singhal, 1993; Laursen \& Foss, 2003), and recruitment (Jiménez \& Sanz-Valle, 2005; Shipton et al., 2005). Through effective HRM practices, employees will be encouraged to experiment new ideas, developed shared understanding with one another, and implement changes in organizational activities, all of which, are likely to contribute to organizational innovation.

Drawing upon the argument given by Shipton et al. (2005), we argued that HRM practices that encourage exploration rather than exploitation can give rise to three types of innovation: product, process, and administrative. Specifically, the higher the level of such practices, the higher would be the level of innovation in products, process, and administration. For instance, extensive training can create the breadth of knowledge necessary to make connections between divergent stimuli (Shipton et al., 2005). Likewise, reward-system based on knowledge would be able to encourage employees to acquire knowledge outside of their own immediate job domain, which in turn, may 
induce them to broaden their horizon and analyze problems in a variety of ways (Laursen \& Foss, 2003). Proper career management can help employees to understand how they fit into the whole organization, thereby enabling them to establish networks across the organization and promote effective coordination (Jiménez-Jiménez \& Sanz-Valle, 2005). Performance appraisal that takes into account one's knowledge and skills can promote creativity among employees (Shipton et al., 2005). Recruitment exercises that utilize psychometric tests and work sampling activities are likely to ensure that employees have the appropriate skills and knowledge which are able to foster creativity (Shipton et al., 2005). Knowledge learnt through such mechanisms will lead to innovations in products, processes, and administrative activities. Thus, of we hypothesized that:

Hypothesis $1\left(\mathbf{H}_{1}\right)$ : The level of HRM Practices (performance appraisal, career management, training, reward system, recruitment) will be positively related to the level of organizational innovation (product innovation, process innovation, administrative innovation).

Our three sub-hypotheses are constructed and Figure 1 depicts our research framework as follows:

$\mathbf{H}_{1 \mathbf{a}}$ : The level of HRM Practices (performance appraisal, career management, training, reward system, recruitment) will be positively related to the level of product innovation.

Hib: The level of HRM Practices (performance appraisal, career management, training, reward system, recruitment) will be positively related to the level of process innovation.

H1c: The level of HRM Practices (performance appraisal, career management, training, reward system, recruitment) will be positively related to the level of administrative innovation.

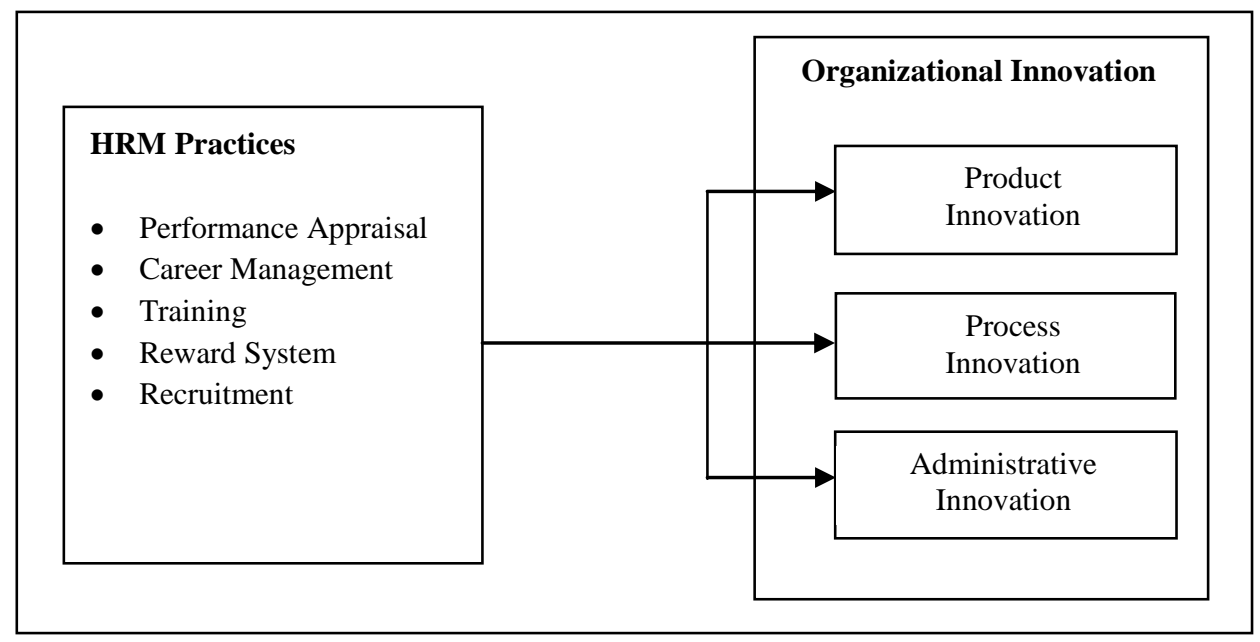

Figure 1 Research framework of the study

\section{Methods and Approach}

The present study is a correlation study (Sekaran, 2003) which attempts to investigate the direct relationship between the level of HRM practices and the level of the three types of organizational innovation: product innovation, process innovation, and administrative innovation. Our respondents comprised of those holding managerial positions, preferably those from the technical functions, such as engineering, process, product, quality, operations, production, and research and development. The Federation of Malaysian Manufacturers (FMM) Directory (2007) was used to identify the manufacturing firms. Questionnaires were sent to 674 firms located in six states of Peninsular Malaysia. These states were identified as having a high percentage of innovating companies (Ministry of Science, Technology and Innovation, Malaysia, 2006). Each participating company was given two months to complete the questionnaire. 
The questionnaire packet consists of 28 items on HRM practices and 13 items on innovation. Specifically, HRM practices comprised of performance appraisal ( 6 items), career management ( 6 items), training (4 items), reward system (6 items), and recruitment (6 items). All items were adapted from Agarwala (2003). Innovation comprised of three types: product innovation measured using four items adapted from Zhang (2006); process innovation measured using four items adapted from US Bureau of Labor Statistics (2008), and administrative innovation measured by five items adapted from Chew (2000). All measures are based on a seven-point Likert scale ranging from (1) 'strongly disagree' to (7) 'strongly agree'.

Our hypotheses were tested using hierarchical multiple regression (Hair, Anderson \& Tatham, 2006). Firm size and years of operation were controlled based on past recommendations (e.g. Jimenez-Jimenez \& Sanz-Valle, 2005; Shipton et al., 2005). The five HRM variables (performance appraisal, career management, training, reward system, and recruitment) served as the independent variables.

\section{RESULTS}

\section{Profile of Participating Companies}

After the specified two months period, 171 useable questionnaires were returned and subsequently analyzed, representing a response rate of 25.4 percent. The profile of the participating companies is shown in Table 1.

Table 1

Profile of Participating Companies

\begin{tabular}{l|c|c}
\hline Variable & Frequency & \% \\
\hline Location of Factory & & 55.5 \\
Northern of Peninsular Malaysia & 95 & 31.0 \\
Central of Peninsular Malaysia & 53 & 13.5 \\
Southern of Peninsular Malaysia & 23 & 26.9 \\
\hline Type of Industry & 46 & 10.5 \\
Electronics / Electrical & 18 & 8.8 \\
Fabricated metal products & 15 & 5.8 \\
Rubber \& plastic products & 10 & 4.7 \\
Textile & 8 & 4.7 \\
Food \& beverages & 8 & 38.6 \\
Motor vehicles & 66 & 35.1 \\
Others & & 44.7 \\
\hline Ownership of Company & 66 & 20.2 \\
100\% foreign company & 84 & \\
100\% local company & 21 & \\
Joint venture company & & \\
\hline
\end{tabular}

A glance at Table 1 indicates that a majority of the participating companies in Malaysia were from northern region $(55.5 \%)$, followed by central region $(31.0 \%)$, and southern region $(13.5 \%)$ respectively. With regard to the type of industry, in terms of proportion, 26.9 percent of the firms came from electronics/electrical industry, 10.5 percent came from fabricated metal products industry, 8.8 percent were from rubber and plastic products industry, 5.8 percent came from the textile industry, 4.7 percent came from the food and beverages industry, and another 4.7 percent were from the motor vehicles industry. The remaining companies came from other industries (38.6\%). In terms of ownership, 44.7 percent are 100\% locally-owned company (44.7\%), followed by 35.1 percent $100 \%$ foreign-owned, and 20.2 percent joint ventures.

\section{Reliability of the Survey Instruments}

As shown in Table 2, the Cronbach's alpha for HRM practices variables were in the range of 0.87 to 0.91 , which exceeded Sekaran's (2003) minimum acceptable level of 0.70 . The reliability coefficients for the three types of innovation were relatively high, which ranged from 0.85 to 0.89 . Therefore, the measures used in this study were considered reliable. 
Table 2

Reliability Coefficients for Variables of the Study

\begin{tabular}{l|c}
\hline Variable & Cronbach Alpha \\
\hline Performance appraisal & 0.87 \\
Career Management & 0.91 \\
Training & 0.89 \\
Reward System & 0.87 \\
Recruitment & 0.82 \\
Product Innovation & 0.89 \\
Process Innovation & 0.88 \\
Administration Innovation & 0.85 \\
\hline
\end{tabular}

Note: $\mathrm{N}=171$.

\section{Descriptive Statistics}

The descriptive statistics for the study variables were tabulated as shown in Table 3. The level of HRM practices in terms of performance appraisal $(\mathrm{M}=5.20, \mathrm{SD}=1.04)$ and training $(\mathrm{M}=5.00, \mathrm{SD}=1.02)$ were rather high. However, the level of HRM practices in terms of career management $(M=4.70, S D=1.04)$, reward system $(M=4.47$, $\mathrm{SD}=1.06)$, and recruitment $(\mathrm{M}=4.21, \mathrm{SD}=0.97)$ were considered moderate.

The mean scores for the three types of innovation were relatively high as follows: administrative innovation $(\mathrm{M}=5.23, \mathrm{SD}=0.94)$, product innovation $(\mathrm{M}=5.10, \mathrm{SD}=0.94)$, and process innovation $(\mathrm{M}=5.05, \mathrm{SD}=0.89)$. In other words, the level of innovation in products, process, and administration were high. We also calculated the mean score for our sample in terms of years in operation $(M=23.20$ years, $S D=10.15)$. Given that the participating companies were wide-ranged in terms of the number of employees (150 to 11000), we decided to compute the median for firm size which was 500 employees.

Table 3

Mean Scores and Standard Deviations for the Study Variables

\begin{tabular}{l|c|c}
\hline Variables & Mean (M) & Standard Deviation (SD) \\
\hline Performance Appraisal & 5.20 & 1.04 \\
Career Management & 4.70 & 1.04 \\
Training & 5.00 & 1.06 \\
Reward System & 4.47 & 0.97 \\
Recruitment & 4.21 & 0.94 \\
Product Innovation & 5.10 & 0.89 \\
Process Innovation & 5.05 & 0.94 \\
Administrative Innovation & 5.23 & 1779.68 \\
\hline Firm size (number of employees) & 500 & 10.15 \\
Years of operation (number of years) & (median) & 23.20 \\
\hline
\end{tabular}

Note: $\mathrm{N}=171$.

\section{Hierarchical Multiple Regression}

Our two-step hierarchical regression results for each of the dependent variables comprising of the three types of innovation are depicted in Table 4, Table 5, and Table 6 respectively.

As shown in Table 4, the two control variables have no effects on product innovation. The $\mathrm{R}^{2}$ value was found to be 0.02 , which means that only $2 \%$ of the variance in product innovation was being explained by these variables. However, on adding the five HRM variables, the $\mathrm{R}^{2}$ change rose to 0.20 . This additional increase of $18.0 \%$ in product innovation was contributed by the HRM practices. On closer examination, only two of the five HRM variables have significant effect on product innovation $(\mathrm{p}=0.01)$. Specifically, training showed a positive effect whereas reward system showed a negative effect on product innovation. These results provided partial support for $\mathrm{H}_{1 \mathrm{a}}$. 
Table 4

Regression Results of the Relationship between Human Resource Management Practices and Product Innovation

\begin{tabular}{|c|c|c|}
\hline Predictors & $\begin{array}{c}\text { Model 1 } \\
\text { Std. } \beta \\
\end{array}$ & $\begin{array}{c}\text { Model } 2 \\
\text { Std. } \beta \\
\end{array}$ \\
\hline \multicolumn{3}{|l|}{ Control Variables } \\
\hline Firm Size & -0.12 & -0.07 \\
\hline Years of operation & 0.09 & 0.02 \\
\hline \multicolumn{3}{|l|}{ HRM Practices } \\
\hline Performance appraisal & & 0.18 \\
\hline Career management & & 0.12 \\
\hline Training & & $0.36 * *$ \\
\hline Reward system & & $-0.28 * *$ \\
\hline Recruitment & & -0.04 \\
\hline $\mathrm{R}^{2}$ & 0.02 & 0.20 \\
\hline Adjusted $\mathrm{R}^{2}$ & 0.01 & 0.16 \\
\hline$\Delta \mathrm{R}^{2}$ & 0.02 & 0.18 \\
\hline F-value & 1.87 & $5.72 * *$ \\
\hline$\Delta \mathrm{F}$-value & 1.87 & $7.12 * *$ \\
\hline
\end{tabular}

Note: $* \mathrm{p}<0.05, * * \mathrm{p}<0.01$

As shown in Table 5, the two control variables have no effects on product innovation. The $\mathrm{R}^{2}$ value was found to be 0.01 , which means that only $1 \%$ of the variance in process innovation was being explained by these variables. However, on adding the five HRM variables, the $\mathrm{R}^{2}$ change rose to 0.19 . This additional increase of $18.0 \%$ in process innovation was contributed by the HRM practices. On closer examination, only two of the five HRM variables have significant effect on process innovation $(\mathrm{p}=0.01)$. Specifically, training showed a positive effect whereas recruitment showed a negative effect on process innovation. These results provided partial support for $\mathrm{H}_{1 \mathrm{~b}}$

Table 5

Regression Results of the Relationship between Human Resource Management Practices and Process Innovation

\begin{tabular}{l|c|c}
\hline Predictors & $\begin{array}{c}\text { Model 1 } \\
\text { Std. } \boldsymbol{\beta}\end{array}$ & $\begin{array}{c}\text { Model 2 } \\
\text { Std. } \boldsymbol{\beta}\end{array}$ \\
\hline Control Variables & & -0.09 \\
Firm Size & -0.11 & -0.05 \\
Years of operation & -0.01 & 0.08 \\
\hline HRM Practices & & 0.19 \\
Performance appraisal & & $0.29^{* *}$ \\
Career management & & 0.03 \\
Training & & $-0.25^{* *}$ \\
Reward system & & 0.19 \\
Recruitment & 0.01 & 0.15 \\
\hline $\mathrm{R}^{2}$ & 0.01 & 0.18 \\
Adjusted $\mathrm{R}^{2}$ & 0.01 & $5.32^{* *}$ \\
$\Delta \mathrm{R}^{2}$ & 1.08 & $6.93^{* *}$ \\
F-value & 1.08 & \\
$\Delta$ F-value & & \\
\hline
\end{tabular}

Note: $* \mathrm{p}<0.05, * * \mathrm{p}<0.01$

As shown in Table 6, the two control variables have no effects on administrative innovation. The $\mathrm{R}^{2}$ value was found to be 0.01 , which means that only $1 \%$ of the variance in administrative innovation was being explained by these variables. However, on adding the five HRM variables, the $\mathrm{R}^{2}$ change rose to 0.31 . This additional increase of $30.0 \%$ in administrative innovation was contributed by the HRM practices. On closer examination, only two of the five HRM variables (training $(p=0.01)$ and performance appraisal $(p=0.05)$ have significant and effects on administrative innovation. These results provided partial support for $\mathrm{H}_{1 \mathrm{c}}$. 
Table 6

Regression Results of the Relationship between Human Resource Management Practices and Administrative Innovation

\begin{tabular}{l|c|c}
\hline Predictors & $\begin{array}{c}\text { Model 1 } \\
\text { Std. } \boldsymbol{\beta}\end{array}$ & $\begin{array}{c}\text { Model 2 } \\
\text { Std. } \boldsymbol{\beta}\end{array}$ \\
\hline Control Variables & & \\
Firm Size & 0.05 & 0.05 \\
Years of operation & 0.06 & 0.01 \\
\hline HRM Practices & & \\
Performance appraisal & & $0.21^{*}$ \\
Career management & & 0.16 \\
Training & & $0.30^{* *}$ \\
Reward system & & -0.03 \\
Recruitment & 0.01 & -0.08 \\
\hline $\mathrm{R}^{2}$ & -0.01 & 0.31 \\
Adjusted $\mathrm{R}^{2}$ & 0.01 & 0.28 \\
$\Delta \mathrm{R}^{2}$ & 0.45 & 0.30 \\
F-value & 0.45 & $10.37^{* *}$ \\
$\Delta$ F-value & & $14.26^{* *}$ \\
\hline
\end{tabular}

Note: $* \mathrm{p}<0.05, * * \mathrm{p}<0.01$

\section{DISCUSSION}

In this study, we sought to examine the effects of HRM practices on organizational innovation. Our statistical results provided partial support for the effects of HRM practices on organizational innovation. Training alone was found to have a positive and significant effect on product innovation, process innovation, and administrative innovation. In other words, the higher the level of training provided by the firms, the higher their level of product innovation, process innovation, and administrative innovation. Through extensive training activities, employees are able to expand their breadth of knowledge, and generate new understandings and new ideas, all of which will be able to stimulate innovations for the organization. Our results are consistent with those by Shipton et al. (2005).

In addition, our study reveals that performance appraisal had a positive effect on administrative innovation ( $\beta$ $=0.21, \mathrm{p}<0.05)$ alone. Proper pperformance evaluation would serve as a guide in moulding and motivating employees to maximize their efforts towards the achievement of the organization's goals. In our study, the feedback associated with performance appraisal may have help improved the administrative activities in the organizations, thereby promoting administrative innovation. Furthermore, the cycle for administrative innovation is relatively shorter compared to both product and process innovation. Generally, these two types of innovation are likely to be longer due to technical constraints which may arise during product and process actualization.

Contrary to expectation, reward system was found to have a negative effect on product innovation. Although a favorable reward-system based on knowledge would be able to encourage employees to think "out of the box", which in turn, may trigger them to become more innovative, our results showed otherwise for product innovation. One explanation for this finding may be that the manufacturing companies sampled were under pressure to reduce cost due to the recent global economic meltdown. Under such circumstances, these firms were more likely to use tight controls, minimize overhead, and pursue economies of scale as suggested by Schuler and Jackson (1987). This is not surprising given the relatively moderate level of rewards offered by these participating companies $(\mathrm{M}=4.47, \mathrm{SD}=$ 1.06). Therefore, when firms enforce tight cost control mechanisms, innovation particularly in terms of new products are likely to suffer. Likewise, recruitment was found to negatively affect process innovation. Although we expect effective recruitment strategies would be able to attract qualified talents with the appropriate skills and knowledge, all of which are able to generate creativity and innovation, our results indicate otherwise for process innovation. One explanation for this finding may be because recruitment strategies tend to apply to new hires. In other words, proper acquisition mechanisms would help the firm recruit people who are talented and motivated to stay with the company for a long time. With the recent economic turbulence, many companies have opted to cut cost through downsizing and hiring contingent workers. As a result, workers' long-term commitments necessary for innovative activities are likely to disappear. Under these circumstances, process innovation which takes a rather long time is likely to be reduced. 
Career management had no effect on the three types of innovation. Although the level of career management strategies employed by the participating firms were moderate $(M=4.70, S D=1.04)$ yet this value was higher compared to reward system $(M=4.47, S D=1.06)$ and recruitment $(M=4.21, S D=0.97)$. An inspection of the sample reveals that the responding companies were diverse in terms of their ownership: locally-owned (44.7\%), foreign-owned (35.1\%), and joint-ventures (20.2\%). One can anticipate that foreign-owned companies are generally more aggressive in developing their employees' career paths as opposed to locally-owned companies (Chew, 2005). Combining these companies in the statistical analysis may have confounded the results leading to an insignificant finding.

\section{CONCLUSION}

In summary, it can be concluded that for this particular study, training as a HRM practice contributed significantly towards explaining the three types of innovation: product, process, and administrative innovation. Our sample comprised of manufacturing companies in Malaysia. As argued by Laursen and Foss (2003), through training, employees are able to expand their breadth of knowledge, and generate new understandings and new ideas, all of which will be able to stimulate organizational innovation. Likewise, our findings also showed that performance appraisal positively affect administrative innovation. Effective performance management would serve as a guide in moulding and motivating employees to maximize their efforts towards the achievement of the organization's goals. Setting performance criteria and giving employees opportunities for feedback would likely improve the administrative mechanisms in the organizations, thereby promoting administrative innovation.

Our findings suggest that since training had a profound effect on organizational innovation, manufacturing firms in Malaysia should strive to continuously provide proper and extensive training to their employees. The knowledge and skills acquire via training would increase employees' task performance and create new ideas which in turn, help enhance product, process and administrative innovation respectively. Similarly, given the positive impact of performance appraisal on administrative innovation, managers in manufacturing firms should place more emphasis on developing effective performance appraisal mechanisms. In this regard, HR managers should focus on quantifiable criteria, give weight to individual as well as team, encourage employee participation, and create open communication, all of which would lead to greater administrative innovation. Despite the fact that our proposed framework was partially validated, our study have served to provide empirical evidence for the importance of HRM particularly training in predicting the three forms of organizational innovation within the context of Malaysia.

The study has several limitations that create fruitful suggestions for future research. First, the data was cross-sectional, so no assumption about causality can be drawn. In particular, the effects of certain HRM practices such as career management may not have immediate effect. Hence, a more appropriate method would be to conduct a longitudinal study. Secondly, this study is limited to the manufacturing industry alone. Hence, our results may be specific to the context of this industry. Future research should be extended to the service industry in order to generalize the results reported here. Thirdly, the use of managerial perceptions to assess innovation performance should be taken as a limitation by incorporating objective measures of innovation in future studies.

\section{AUTHOR INFORMATION}

Dr. Tan Cheng Ling is a senior lecturer at the Graduate School of Business, Universiti Sains Malaysia (USM). She teaches Operations Management at both undergraduate and postgraduate levels. Dr. Cheng Ling's current research area is in knowledge management and innovation. Prior to joining USM, she was a quality manager for 10 years in two multinational companies in Malaysia.

Dr. Aizzat Mohd. Nasurdin is an Associate Professor at the School of Management, Universiti Sains Malaysia (USM). She teaches courses in management and organizational behavior at the undergraduate and postgraduate levels. She also supervises postgraduate students in the field of organizational behavior. Dr. Aizzat's area of interest includes work behavior, organizational justice, commitment, and innovation. 


\section{REFERENCES}

1. Agarwala, T., Innovative Human Resource Practices and Organizational Commitment: An Empirical Investigation, International Journal of Human Resource Management, Vol. 14, No. 2, pp. 175-197, 2003.

2. Chen, C. and J. Huang, How Organizational Climate and Structure Affect Knowledge Management: The Social Interaction Perspective, International Journal of Information Management, Vol. 27, No. 2, pp. 104-118, 2007.

3. Chew, C. H., Organizational Cultural Characteristics and Innovation: A Perspective from Electrical and Electronics Industry in Penang, Unpublished M.B.A dissertation, Universiti Sains Malaysia, Penang, Malaysia, 2000.

4. Chew, Y. T., Achieving Organizational Prosperity through Employee Motivation and Retention: A Comparative Study of Strategic HRM Practices in Malaysian Institutions, Research and Practice in Human Resource Management, Vol. 13, No. 2, pp. 87-104, 2005.

5. Chuang, L-M., An Empirical Study of the Construction of Measuring Model for Organizational Innovation in Taiwanese High-Tech Enterprises, The Journal of American Academy of Business, Vol. 9, No. 2, pp. 299-304, 2005.

6. Damanpour, F., Organizational Innovation: A Meta-Analysis of Effects of Determinants and Moderators, Academy of Management Journal, Vol. 34, No. 3, pp. 555-590, 1991.

7. Damanpour, F., Organizational Complexity and Innovation: Developing and Testing Multiple Contingency Models, Management Science, Vol. 42, No. 5, pp. 693-716, 1996.

8. Damanpour, F. and W. M. Evan, Organizational Innovation and Performance: The Problem of Organizational Lag, Administrative Science Quarterly, Vol. 29, No. 3, pp. 329-409, 1984.

9. Damanpour. F. and S. Gopalakrishnan, The Dynamics of the Product and Process Innovations in Organizations, Journal of Management Studies, Vol. 38, No. 1, pp. 45-65, 2001.

10. Damanpour, F., K. A. Szabat, and W. M. Evan, The Relationship Between Types of Innovation and Organizational Performance, Journal of Management Studies, Vol. 26, No. 6, pp. 587-601, 1989.

11. Delery, J. E. and D. H. Doty, Modes of Theorizing in Strategic Human Resource Management: Tests of Universalistic, Contingency, and Configurational Performance Predictions, Academy of Management Journal, Vol. 39, No. 4, pp. 802-835, 1996.

12. Dyer, L., Strategic Human Resource and Planning. In K. Rowland and G. Ferris (Ed. Research in Personnel and Human Resource Management, Vol. 3, pp. 1-30. Greenwich, CT: JAI Press, 1985.

13. European Commission, Singapore and European Union: R\&D Cooperation for the Future. Luxembourg: Office for Official Publications of the European Communities, 2006.

14. Federation of Malaysian Manufacturers Directory, Malaysian Industries (38th ed.). Malaysia: Federation of Malaysian Manufacturers, 2007.

15. Ferris, G. R., W. A. Hochwarter, M. R. Buckley, G. Harrell-Cook and D. D. Frink, Human Resource Management: Some New Directions. Journal of Management, Vol. 23, No. 3, pp. 385-415, 1999.

16. Gupta, A. and A. Singhal, Managing Human Resources for Innovation and Creativity, Research Technology Management, Vol. 36, No. 3, pp. 8-41, 1993.

17. Hage, J. and J. R. Hollingsworth, A Strategy for the Analysis of Idea Innovation Networks and Institutions, Organizational Studies, Vol. 21, No. 5, pp. 971-1004, 2000.

18. Hair, J. F., R. L. Anderson and W. C. Tatham, Multivariate Data Analysis with Reading (6th ed.). Upper Saddle River, NJ: Prentice-Hall, 2006.

19. Harter, J. K., F. L. Schmidt and T. L. Hayes, Business-Unit-Level Relationship Between Employee Satisfaction, Employee Engagement, and Business Outcomes: A Meta-Analysis, Journal of Applied Psychology, Vol. 87, No. 2, pp. 268-279, 2002.

20. Hiltrop, J. M., Managing the Changing Psychological Contract, Employee Relations, Vol. 18, No. 1, pp. 3649, 1996.

21. Huselid, M. A., The Impact of Human Resource Management Practices on Turnover, Productivity and Corporate Financial Performance. Academy of Management Journal, Vol. 38, No. 3, pp. 635-672, 1995.

22. Ismail, M., Creative Climate and Learning Organization Factors: Their Contribution towards Innovation, Leadership \& Organization Development Journal, Vol. 26, No. 7/8, pp. 639-655, 2005.

23. Jackson, S. E. and R. S. Schuler, Understanding Human Resource Management in the Context of Organizations and Their Environments, Annual Review of Psychology, Vol. 46, No. 1, pp. 237-260, 1995. 
24. Jackson, S. E., R. S. Schuler and J. C. Rivero, Organizational Characteristics as Predictors of Personnel Practices, Personnel Psychology, Vol. 42, No. 4, pp. 727-786, 1989.

25. Jiménez-Jiménez, J. and R. Sanz-Valle, Innovation And Human Resource Management Fit: An Empirical Study, International Journal of Manpower, Vol. 26, No. 4, pp. 364-381, 2005.

26. Johnson, J., J. R. Baldwin, and B. Diverty, The Implications of Innovation for Human Resource Strategies, Futures, Vol. 28, No. 2, pp. 103-119, 1996.

27. Kimberly, J. R. and M. Evanisko, Organizational Innovation: The Influence of Individual, Organizational, and Contextual Factors on Hospital Adoption of Technological and Administrative Innovation, Academy of Management Journal, Vol. 24, No. 4, pp. 689-713, 1981.

28. Kydd, C. T. and L. Oppenheim, Using Human Resource Management to Enhance Competitiveness: Lessons from Four Excellent Companies, Human Resource Management, Vol. 29, No. 2, pp. 145-166, 1990.

29. Laursen, K. and N. J. Foss, New Human Resource Management Practices, Complementarities and the Impact on Innovation Performance, Cambridge Journal of Economics, Vol. 27, No. 2, pp. 243-263, 2003.

30. Lundvall, B-K. and P. Nielson, Knowledge management and innovation performance, International Journal of Manpower, Vol. 28, No. 3/4, pp. 207-223, 2007.

31. Mavondo, F. T., J. Chimhanzi and J. Stewart, Learning Orientation and Market Orientation: Relationship with Innovation, Human Resource Practices and Performance, European Journal of Marketing, Vol. 39, No. 11, pp. 1235-1263, 2005.

32. Miller. D. and P. H. Friesen, Innovation in Conservative and Entrepreneurial Firms: Two Models of Strategic Momentum, Strategic Management Journal, Vol. 3, No. 1, pp. 1-25, 1982.

33. Ministry of Science, Technology and Innovation, Malaysia, National Survey of Innovation 2002-2004, Putrajaya: Malaysian Science and Technology Information Centre, 2006.

34. Mohamed, M. Z., Innovation Implementations in Malaysian Firms: Process, Problems, Critical Success Factors and Working Climate, Technovation, Vo. 16, No. 6, pp. 375-385, 1995.

35. Paauwe, J. and P. Boselie, HRM and Performance: What's Next? Human Resource Management Journal, Vol. 15, No. 4, pp. 68-83, 2005.

36. Prime Minister's Department, Malaysia, Ninth Malaysia Plan 2006-2010, Putrajaya, Malaysia: The Economic Planning Unit, 2006.

37. Rousseau, D. M., and M. M. Greller, Human Resource Practices: Administrative Contract Makers, Human Resource Management, Vol. 33, No. 3, pp. 385-401, 1994.

38. Schaffer, R. H. and C. M. Paul-Chowdhury, Implementation: There's More to Innovation Than Great Ideas, Ivey Business Journal, November/December, pp. 1-6, 2002.

39. Schuler, R. S., Strategic Human Resource Management and Industrial Relations, Human Relations, Vol. 42, No. 2, pp. 157-184, 1989.

40. Schuler, R. S. and S. E. Jackson, Linking Competitive Strategies with Human Resource Management Practices, Academy of Management Executive, Vol. 1, No. 3, pp. 207-219, 1987.

41. Shipton, H., D. Fay, M. West, M. Patterson and K. Birdi, Managing People to Promote Innovation, Creativity and Innovative Management, Vol. 14, No. 2, pp. 118-128, 2005.

42. U. S. Bureau of Labor Statistics, Washington: United States Department of Labor, 2008. Retrieved October 8, 2008, from http://www.bls.gov/news.release/pdf/empsit.pdf

43. Wan Jusoh, W. J., Determining Key Success Factors in New Product Development: Evidence from Manufacturing Companies in Malaysia, Journal of International Business and Entrepreneurship, Vol. 8, No. 1, pp. 21-40, 2000.

44. Wolfe, R., Human Resource Management Innovations: Determinants of their Adoption and Implementation, Human Resource Management, Vol. 34, No. 2, pp. 313-327, 1995.

45. Wong, P. K. and Z. L. He, The Moderating Effect of a Firm's Internal Climate for Innovation on The Impact of Public R\&D Support Programs, International Journal of Entrepreneurship and Innovation Management, Vol. 3, No. 5/6, pp. 525-545, 2003.

46. Wright, P. M. and G. C. McMahan, Theoretical Perspectives for Strategic Human Resource Management, Journal of Management, Vol. 18, No. 2, pp. 295-320, 1992.

47. Zain, M. M. and T. Rickards, Assessing and Comparing the Innovativeness and Creative Climate of Firms, Scandinavian Journal of Management, Vol. 12, No. 2, pp. 109-122, 1996.

48. Zhang, J., Knowledge Flow Management and Product Innovation Performance: An Exploratory Study on MNC Subsidiaries in China, Published Doctoral of Philosophy dissertation, Temple University, USA: Graduate School, 2006. 
NOTES 